\title{
Water deficit altered proline and chlorophyll concentrations, and 1-Amino-cyclopropane-1- Carboxylic-Acid Oxydase accumulation in white clover
}

\author{
Aluh Nikmatullah ${ }^{13^{*}}$, Michael T. McManus ${ }^{1}$, M. Hossein Behboudian ${ }^{2}$, Susanna Leung ${ }^{1}$ \\ ${ }^{1}$ Institute of Molecular Biosciences, Massey University, Private Bag 11, 222 Palmerston North, 4442, New Zealand \\ ${ }^{2}$ Institute of Agriculture and Environment, Massey University, Private Bag 11, 222 Palmerston North, 4442, New Zealand \\ ${ }^{3}$ Faculty of Agriculture, University of Mataram, Jn. Majapahit 62 Mataram, 83127, Indonesia (Present Address) \\ *Corresponding Author E-mail: aluh_nikmatullah@unram.ac.id
}

\begin{tabular}{|c|c|}
\hline \multirow[t]{2}{*}{ matullah } & $\begin{array}{l}\text { Abstract. The effect of water deficit on concentration of proline and chlorophyll, as } \\
\text { well as ACC oxydase gene expression and protein accumulation was examined in white } \\
\text { clover subjected to water deficit. The water deficit treatment was imposed by a } \\
\text { complete withholding of water and examined until the PER ceased (at -1,4 MPa). The } \\
\text { water deficit below } 20 \% \text { caused a decrease in the LWP and PER, but an increase in the } \\
\text { total chlorophyll and proline concentrations of the FFE leaves. However, the total } \\
\text { chlorophyll of the SFE leaves did not altered by water deficit imposion. The expression } \\
\text { of specific ACO genes and accumulation of ACO protein were examined within the } \\
\text { tissues in which each gene is expressed during natural leaf ontogeny. No changes in } \\
\text { TR-ACO1 expression and TR-ACO1 protein accumulation were determined in the } \\
\text { apex. However, expression of the developing-leaf associated TR-ACO2 and } \\
\text { accumulation of TR-ACO2 protein in the FFE leaves was stimulated further by water } \\
\text { deficit treatment. This was most marked in an SWC associated with a decrease in PER, } \\
\text { but before the significant change of rapid proline accumulation occurred. For the leaf } \\
\text { senescence-associated TR-ACO3, no changes in expression were observed over the } \\
\text { two stages of leaf development examined, suggesting that the severity and time-frame } \\
\text { of exposure to the water deficit was not sufficient to induce this gene. These results } \\
\text { show that water deficit does induce changes in the ACC Oxydase particularly the TR- } \\
\text { ACO2 in the FFE leaf, and the changes were associated with an increase in chlorophyll } \\
\text { and proline accumulation. }\end{array}$ \\
\hline & $\begin{aligned} & \text { Cite as: } \text { Nikmatullah, A., McManus, M.T., Behboudian, M.H., \& Leung, S. (2021). } \\
& \text { Water deficit altered proline and chlorophyll concentrations, and 1-Amino- } \\
& \text { cyclopropane-1-Carboxylic-Acid Oxydase accumulation in white clover. } \\
& \text { Journal of Sustainable Dryland Agricultural Systems, 1(1), 1-12. DOI: } \\
& \text { https://dx.doi.org/10.29303/josdas.v01i1.01 }\end{aligned}$ \\
\hline
\end{tabular}




\section{INTRODUCTION}

Water availability is crucial to sustain crop production worldwide; however adequate water availability may be a problem for wellbeing and agriculture in the future. Climate change has altered the rain pattern and thus water availability, including for agricultural purposes. The impact may be worse in the arid and semi-arid dry-lands, such as West Nusa Tenggara (WNT), as the landscapes are characterized by limited water resources and prone to land degradation (Ravi et al., 2010), and thus water deficit is a major limitation for agricultural production in dry land areas. The Soil water deficit is one of the most important factors influencing in plant growth and productivity (Ramasamy et al., 2017). Therefore, understanding the plant responses to water deficit stress is important for a better agricultural management, particularly for arid and semi-arid regions.

The growth response of plants to water deficit is complex involving responses that occur at the morphological, physiological, cellular and metabolic levels (Rodriguez-Uribe \& O'Connell, 2006). Water deficit decreased leaf water potential and increased leaf osmotic potential (McManus et al., 2000), and directly affected cell division, cell enlargement and cell differentiation (Schroeder et al., 2001; Sanchez et al., 2004). Increase in leaf osmotic potential had been shown to alter accumulation of compatible solutes and alteration or change in the balance of plant hormones (e.g. Chen et al., 2002; Tanaka et al., 2005). Amongst the Compatible solutes induced by water deficit us protective protein and amino acids, such as proline (McManus et al., 2000).

Other responses of plants to water deficit stresses is premature necrosis (leaf senescence) and abscission in mature leaves (Bleecker \& Kende, 2000), driven by an increased in ethylene concentration such as in leaf of maize (Young et al., 2004). Premature leaf senescence processes in vegetative plants is associated with a decrease in total chlorophyll content (Javadi et al., 2008; Guerfel et al., 2009).

Ethylene is a simple unsaturated gaseous plant hormone. Ethylene is continuously present during the whole plant life cycle (Bleecker \& Kende, 2000), and has an important role in the regulation of many physiological responses of plants (Bleecker \& Kende, 2000). Ethylene is produced by the majority of higher plant in various stages of plant growth and development from initiation to maturation and senescence (eg. Hunter et al., 1999; Chen \& McManus, 2006). In addition, various environmental cues such as wounding, pathogen attack, flooding, drought, anoxia, ozone and light has also been shown to alter ethylene biosynthesis in plants (Yang \& Hoffmann, 1984; Bleecker \& Kende, 2000) and so the hormone is proposed to be an important regulator of the response of the plant to these various stimuli.

The key step in ethylene biosynthesis is the conversion of AdoMet to ACC, by the enzyme ACC synthase and the oxidative cleavage of ACC by the enzyme ACC oxidase into ethylene (Yang \& Hoffmann, 1984; Bleecker \& Kende, 2000; Wang et al., 2002). ACC oxidase (ACO; EC 1.14.17.4) is the enzyme that catalysis the final step of ethylene biosynthesis, which is the conversion of ACC into ethylene (Yang \& Hoffmann, 1984). ACO is encoded by a small multi-gene family in many plant species, and there are three members of ACO have been identified and isolated from white clover, i.e. TR-ACO1, TR-ACO2 and TR-ACO3 (Hunter et al., 1999). The ACO gene expression has been shown to be developmentally regulated (Hunter et al., 1999). In white clover, grown in normal condition, expression of TR-ACO1, TR-ACO2 and TR-ACO3 occur in different stages of leaf development (Hunter et al., 1999). In addition evidence is now emerging to suggest that ACO multigene family gene expression is responsive to abiotic or environmental cues such as wounding, ethylene treatment (Higgins et al., 2006) and submergence (Rieu et al., 2005). 
In this paper, we use white clover (Trifolium rapens L.) as a model plants to investigate physiological responses of plant to water deficit, and to examine the role of ethylene in plant adaptation to a water deficit stress by investigating changes in ACC oxidase gene expression and ACC oxidase protein accumulation as well as proline and chlorophyll concentration in different developmental stages of white clover leaves under water deficit condition.

\section{MATERIAL AND METHODS}

The experiment were conducted in The New Zealand Control Environment Laboratory (NZCEL), Plant and Food Research, Palmerston North, New Zealand from November to December in 2007. The NZCEL conditions were maintained at a constant temperature of $21^{\circ} \mathrm{C}$ (day) and $14^{\circ} \mathrm{C}$ (night), constant relative humidity of $75 \%$ and $\mathrm{CO}_{2}$ at $350 \mathrm{ppm}$. The room was equipped with $4 \mathrm{x}$ Metal Halide $(1.0 \mathrm{~kW})$ and $4 \mathrm{x}$ Tungsten Halogen $(1.0 \mathrm{~kW})$ lights providing $650 \mu \mathrm{mm}-{ }^{2} \mathrm{~s}^{-1}$ PFD over a $14 \mathrm{~h}$ photoperiod and with built-in mirrors, placed on all of the walls $1.5 \mathrm{~m}$ above the floor, to provide uniform illumination to all parts of the room. The white clover plants (Kopu variety) were acclimatized for 1 week before the water deficit treatment by the complete withholding of water.

The growth (petiole elongation rate/PER), soil water content (SWC) and leaf water potential (LWP) were measured daily until PER was ceased, at 3-5 hours after dawn, four pots per day (destructively). The SWC was estimated using electrical conductivity probes placed at a $15 \mathrm{~cm}$ depth connected to a TDR (Time Domain Refractometer) apparatus (Trase Soil Moisture Measuring System, Soil moisture Equipment Corp, Santa Barbara CA, USA). The LWP was measured in the first fully-expanded leaves by a Scholander pressure chamber (Soil moisture Equipment Corp, Santa Barbara CA, USA) while the PER was calculated as the rate of petiole extension per day (as $\mathrm{mm} / \mathrm{cm} /$ day).

The tissue samples were exised from the plant daily and directly freezed in liquid nitrogen, then stored in $-80^{\circ} \mathrm{C}$ until required. The leaf chlorophyll was extracted in chilled $\left(4^{\circ} \mathrm{C}\right) \mathrm{DMF}$ in darkness at $4^{\circ} \mathrm{C}$ for $14 \mathrm{~h}$, and the absorbance was read at both 647 and $665 \mathrm{~nm}$ against a DMF blank. The total chlorophyll concentrations were calculated as $17.9 \mathrm{~A}_{647}+8.08 \mathrm{~A}_{664.5}(\mathrm{mg} / \mathrm{mL})$ (Inskeep \& Bloom, 1985). Proline was extracted according to method described by Magne and Larher (1984) and the absorbance was read at $518 \mathrm{~nm}$ against a toluene blank. Leaves protein was extracted with 3 volume of extraction buffer at $4^{\circ} \mathrm{C}$. The protein concentration was estimated by a microassay version of the Bradford method with BSA as the protein standard.

SDS PAGE (Sodium dodecyl sulfate-polyacrylamide gel electrophoresis) was undertaken according to method described by Laemmli (1970) with some modifications. The protein samples were mixed with two volumes of $2 \times$ SDS gel loading buffer, incubated in a boiling water bath for 3 min and then cooled for $10 \mathrm{~min}$ at room temperature, centrifuged at $10000 \mathrm{x} \mathrm{g}$ for $1 \mathrm{~min}$ at room temperature, and loaded into the gel wells with molecular weight markers was loaded separately as required, and then electrophoreses at $100 \mathrm{~V}$ for $130 \mathrm{~min}$. The gels were transfered to a Polyscreen polyvinyl fluoride membrane (PVDF, PerkinElmer ${ }^{\mathrm{TM}}$ Life Sciences, Inc., Boston, USA) using a Trans-Blot Electrophoretic Transfer Cell (Bio-Rad) at $100 \mathrm{~V}$ for 1 hour at room temperature (with ice block and continuous stirred) The membrane was blocked at room temperature for $2 \mathrm{~h}$, with gentle shaking, incubated with primary antibody for 1 hour at $37^{\circ} \mathrm{C}$ with gentle shaking, followed by incubation with secondary antibody for $1 \mathrm{~h}$ at room temperature with gently shaking. After washing, the protein was detected using the chemiluminescent method according to the instructions supplied 
by Thermo Fisher Scientific, by SuperSignal and then developed on a piece of X-ray film using an automatic X-ray film processor (100Plus ${ }^{\mathrm{TM}}$, All Pro Image, Hickville, NY, USA).

Total RNA was isolated using the hot borate method (Hunter and Reid, 2001) with some modifications. The first single strand of complementary DNA (cDNA) was synthesised by the ThermoScript ${ }^{\mathrm{TM}}$ RT-PCR system (Invitrogen) using an oligo (dT) primes and $4 \mu \mathrm{g}$ total RNA. The mixtures were denatured at $65^{\circ}$ for $5 \mathrm{~min}$ the incubated on ice for $2 \mathrm{~min}$ before addition of cDNA synthesis buffer, DTT, RNaseOUT and ThermoScript ${ }^{\mathrm{TM}} \mathrm{RT}$. The cDNA synthesis was carried out at $50^{\circ} \mathrm{C}$ for $60 \mathrm{~min}$, and reaction terminated at $85^{\circ} \mathrm{C}$ for $5 \mathrm{~min}$. RNase $\mathrm{H}$ was then added to digest any remaining RNA by incubation at $37^{\circ} \mathrm{C}$ for $20 \mathrm{~min}$. Amplification of $T R-A C O$ transcripts were carried out using the PCR Master Mix Kit (Promega). The sequences of primers used were CACCAGCACCAAACTTTAT (TR-ACOI forward), AAGAGAATAATGAAGTTTACC (TRACO2 forward), AAAAGAAACAGAGGAAAAAA (TR-ACO3 forward), TCTAAAATCAAACTTTAATCAT (TR-ACO1 reverse), CACTCACTATATAGTAAGTAAACA (TR-ACO2 reverse), GATGTTCGAACTCTAATCCC (TR-ACO3 reverse), TGAAGTACCCCATCGAGCACG $(\beta$-actin forward) and AGTGATCTCCTTCTGCATCCTGT $(\beta-$ actin reverse). The conditions for amplification of specific TR-ACO transcripts were undertaken for 15 cycles and then separated by horizontal $1 \%(\mathrm{w} / \mathrm{v})$ agarose gels electrophoresis with $1 \mathrm{xTAE}$ buffer, transfered to Hybond ${ }^{\mathrm{TM}}-\mathrm{N}^{+}$nylon membrane (Amersham, GE Healthcare UK Limited, Buckinghamshire UK) by ownward alkaline capillary transfer and then probed with Dig_labbeled specific gene, and developed in an X-ray film (Kodak) using an automatic X-ray film processor (100Plus ${ }^{\mathrm{TM}}$, All Pro Image, Hickville, NY, USA).

\section{RESULTS AND DISCUSSION}

\subsection{Physiological changes accompanying the changes in soil water content}

In this study, changes in LWP and PER as SWC decreases were measured in the FFE-leaves while chlorophyll and proline contents were measured in the SFE-leaves of plants exposed to the water deficit treatments until the petiole elongation rate (PER) ceased. The SWC progressively declined from $\mathrm{ca}$. 30\% (well-watered condition) to $8 \%$ after 7 days of water deficit imposion (Fig. 1A). For LWP, a value of -5.5 bar was recorded in leaves of fully-turgid plants which decreased to an approximately $c a$. -9 bar, at $18 \%$ SWC. The LWP then further decreased to $c a$. -18 bar at $8 \%$ SWC, the point at which the PER ceased (Fig. 1A).Under well-watered conditions, a PER of $c a .9 .5 \mathrm{~mm}$ per day was observed, and the rate was maintained at above 20\% SWC (Fig. 1C). The first significant decline in the PER (i.e. when the rate was significantly lower than that recorded for the fully hydrated leaf tissue) was first observed at $17.5 \%$ SWC after which the PER gradually declined as the SWC decreased until it ceased at $8 \%$ SWC (Fig. 1B).

For proline content, the FFE-leaves of well-watered plants accumulated $c a .80 \mu^{g} \mathrm{~g}^{-1} \mathrm{FW}$ which remained between 60 and $80 \mu \mathrm{g} \mathrm{g}^{-1} \mathrm{FW}$ as the SWC decreased until 11.9\%, after which the proline content increased significantly to $346 \mu \mathrm{g} \mathrm{g}^{-1} \mathrm{FW}$ at $9.1 \%$ SWC. After this point, the proline concentration declined to $c a$. $180 \mu \mathrm{g} \mathrm{g}^{-1} \mathrm{FW}$ when the PER ceased (at $8 \% \mathrm{SWC}$ ). The proline concent of fully-hydrated SFE-leaves was $c a .80 \mu \mathrm{g} \mathrm{g}^{-1} \mathrm{FW}$, and the concentration increased gradually as the SWC decreased to reach $170100 \mu \mathrm{g} \mathrm{g}^{-1} \mathrm{FW}$ at $11.9 \%$ SWC and continue to increased to $310 \mu \mathrm{g} \mathrm{g}^{-1}$ FW at $8 \%$ SWC, when PER ceased $8 \%$ SWC (Fig. 1-D). 

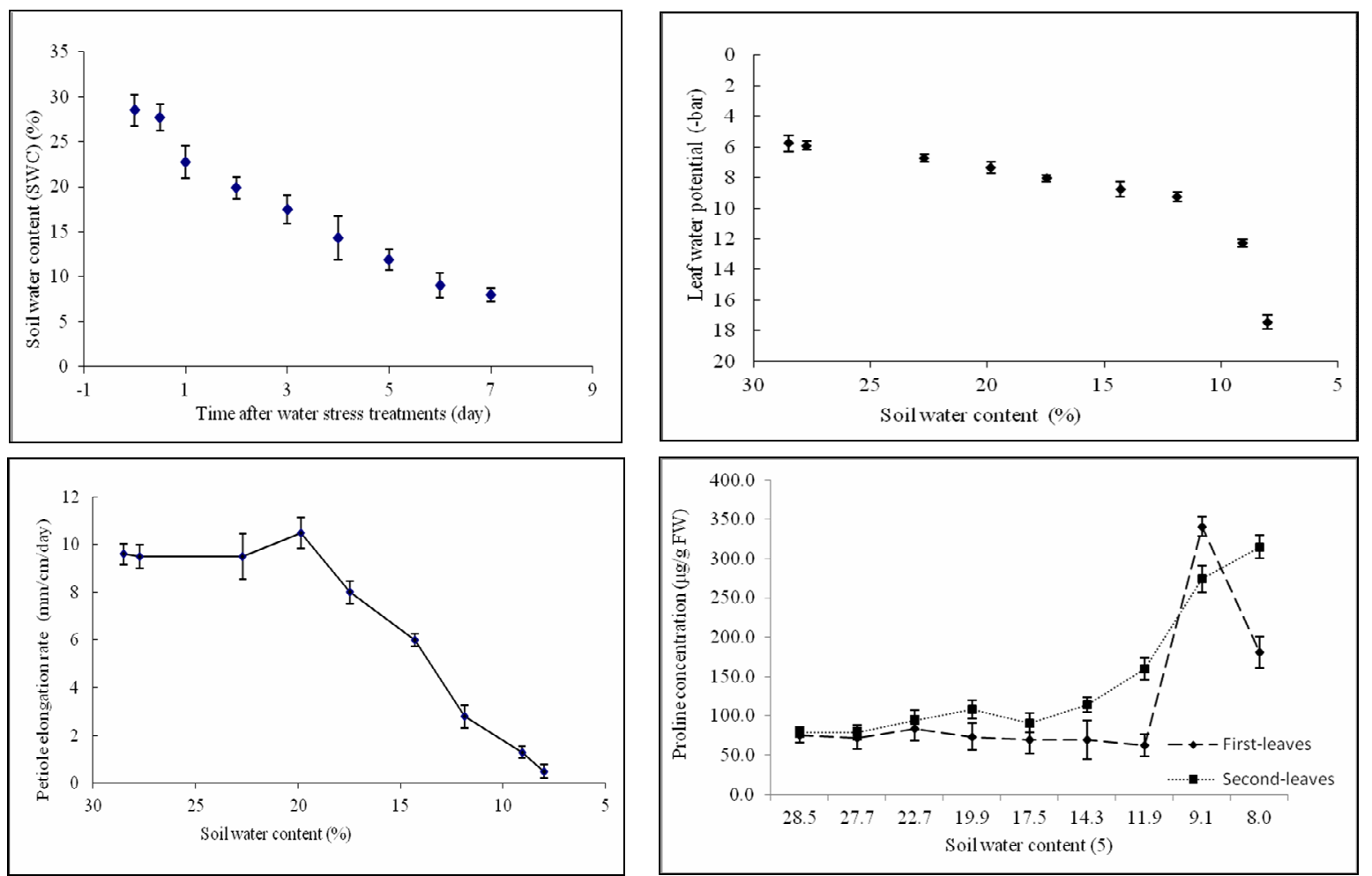

Fig 1. Changes in the SWC, LWP and PER over the time of water deficit exposure in the FFE-leaves, as well as proline content in the FFE- and SFE-leaves of white clover subjected to a water deficit condition

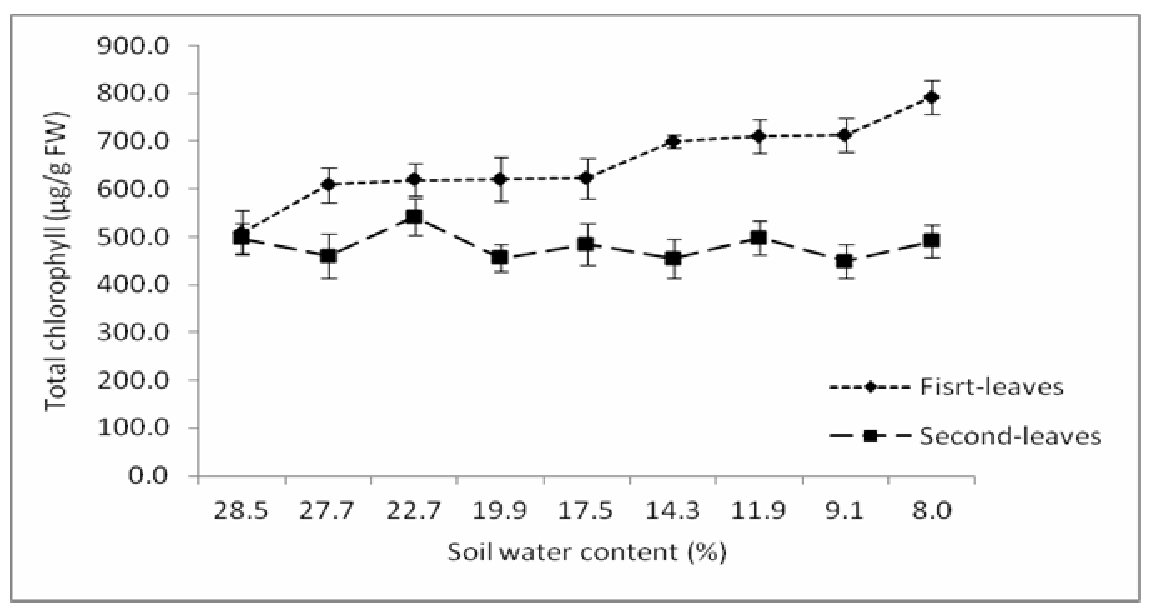

Fig 2. The total chlorophyll of the FFE-leaves and the SFE-leaves over the time course of experiment as response of white clover plant to water deficit imposion.

Total chlorophyll in the FFE-leaves was measured as the SWC decreased, with little changes at SWC above $17 \%$ ranging from ca. $510 \mu \mathrm{g} \mathrm{g}^{-1} \mathrm{FW}$ to $610 \mu \mathrm{g} \mathrm{g}^{-1} \mathrm{FW}$. However, the total chlorophyll of FFE-leaves increased to $c a 710 \mu \mathrm{g} \mathrm{g}^{-1} \mathrm{FW}$ at $14.3 \% \mathrm{SWC}$, and continue to increase to $800 \mu \mathrm{g} \mathrm{g}^{-1}$ FW when PER ceased at $8 \%$ SWC (Fig. 2). Changes in chlorophyll content was also measured in the next older SFE-leaves. In the SFE leaves, total chlorophyll contents were not significantly altered by water deficit, at arround 450 to $540 \mu \mathrm{g} \mathrm{g}^{-1} \mathrm{FW}$ over the course of the experimentation (Fig. 2). 
3.2. Differential expression of the TR-ACO multi-gene family and accumulation of ACO protein isoforms in defined tissues over the water deficit time-course

The expression of TR-ACO1 and accumulation of TR-ACO1 in the apical tissues of the stolon was examined over the time-course of decreasing SWC from fully-hydrated to the point at which the PER ceased (Fig. 3). Over the cource of water deficit imposion, no significant and consistent change in TR-ACO1 expression (Fig 3A) or TR-ACO1 accumulation was observed (Fig. 3B).

The expression of TR-ACO2 and accumulation of TR-ACO2 was then examined in the FFE- and SFE-leaves (Fig. 4 and Fig. 5). For the FFE-leaves, the expression of TR-ACO2 and accumulation of TR-ACO2 started to increase at $17.5 \%$ SWC, and continued to increase until the PER was ceased at $8 \%$ (Fig. 4). However, no real change was observed in both expression of TR-ACO2 and accumulation of TR-ACO2 in the SFE-leaves over the course of the experiment (Fig. 5). In addition there was also no real changes in the expression of TR-ACO3 in this older leaf (Fig. 6).
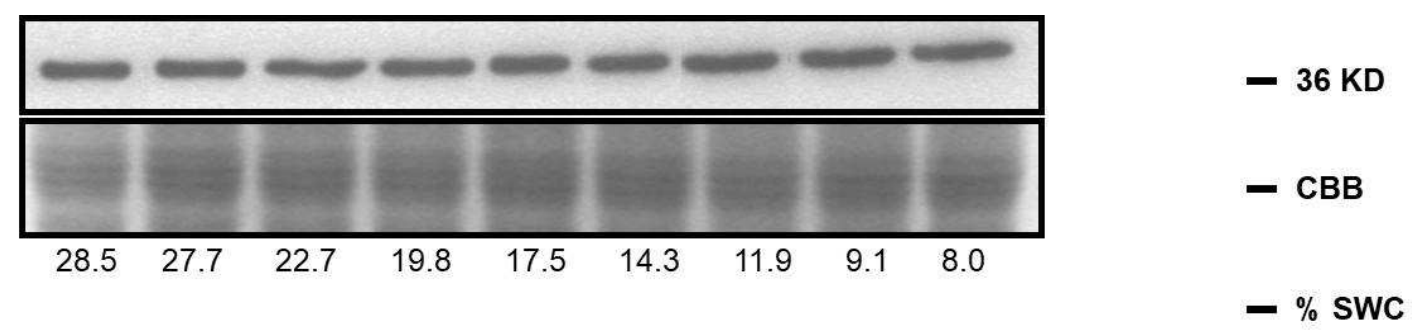

Fig 3. RT-PCR analysis for TR-ACO1 expression (A) and western blot analysis for accumulation of TR-ACO1 in the apex at different water deficit condition

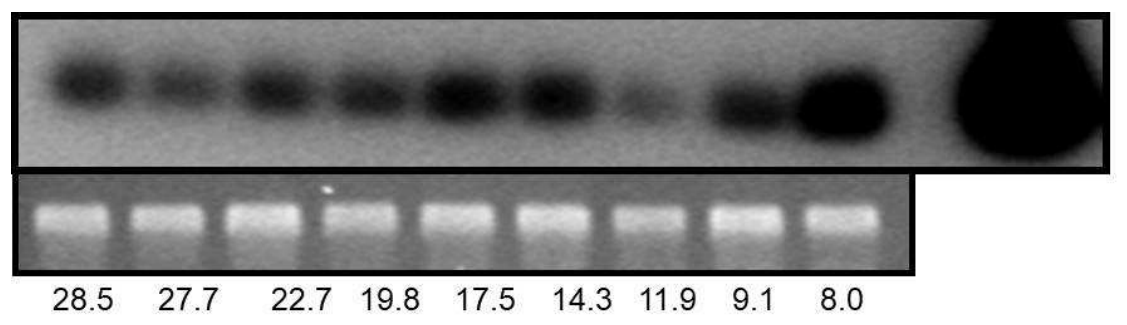

\author{
TR-ACO2 \\ B-actin \\ $\%$ SWC
}

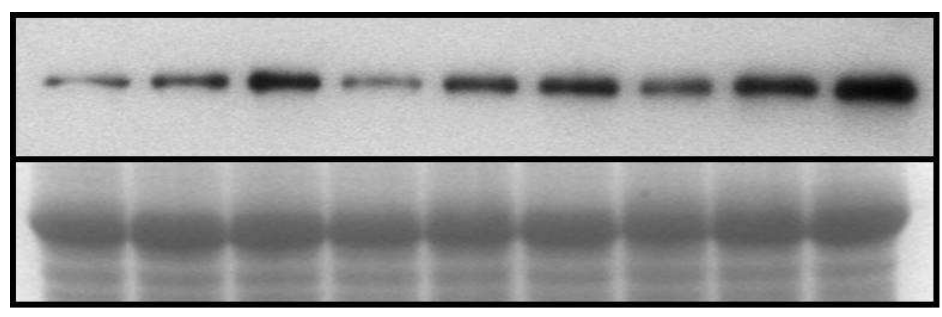

TR-ACO2

CBB

SWC (\%)

Fig 4. RT_PCR analysis for expression of TR-ACO2 (A) and western blot analysis for accumulation of TR$\mathrm{ACO} 2(\mathrm{~B})$ in the FFE- leaves at different water deficit condition

This study has sought to investigate the effects of a water deficit on proline and chlorophyll concentration, as well as 1-Amino-cyclopropane-1-Carboxylic-Acid (ACC) oxydase gene expression and protein accumulation using the pasture legume white clover. To examine such control, the experiment was conducted in the climate room (NZCL) to ensue equal environmental condition to all plants over the course of the experiment. In terms of physiological changes in the plant to water deficit, the PER was observed to firstly declined at $18 \%$ SWC, at the time of significant decrease in LWP from -5.5 bar to an approximately $c a$. -9 bar. A reduction in vegetative growth rate is widely 
considered as a positive adaptive response by plants to ameliorate the effects of drought (Skirycz \& Inze, 2010), and while such reduction occurs the proline accumulation start to increase in the FFEleaves and SFE-levaes. The increase in proline content of SFE-leaves is more profound than the FFEleaves suggesting different degree of water stress in the FFE- and SFE-leaves.

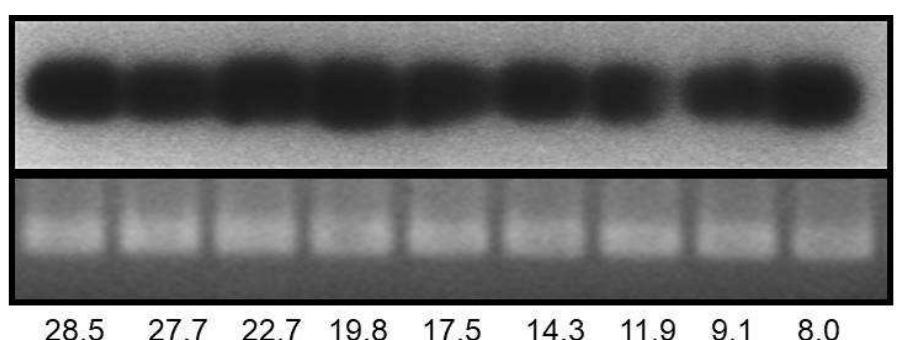

TR-ACO2

B-actin

$\%$ SWC

Fig 5. RT_PCR analysis for expression of TR-ACO2 (A) and western blot analysis for accumulation of TR$\mathrm{ACO} 2(\mathrm{~B})$ in the SFE- leaves at different SWC

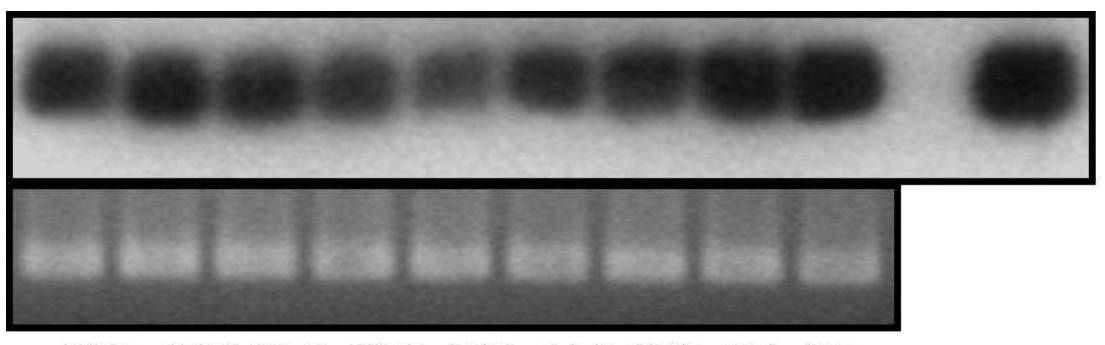

$\begin{array}{lllllllll}28.5 & 27.7 & 22.7 & 19.8 & 17.5 & 14.3 & 11.9 & 9.1 & 8.0\end{array}$

TR-ACO3

B-actin

$\%$ SWC

Fig 6. RT-PCR analysis for expression of TR-ACO3 in the SFE-leaves at different SWC

In terms of ethylene evolution from the FFE- and SFE-leaves, a discrete small, but significant, increase at the first perceptible decrease in SWC was observed in the FFE-leaves. In this study, we have exposed plants to a water deficit until the PER ceased (at ca. -18 bar or 1.8 MPa) which is considered a milder water stress (Yang et al., 2006). Further, the rate of LWP decrease occurred over a range of ca. -0.6 to $1.3 \mathrm{bar} /$ day $(-0.06$ to $-0.13 \mathrm{MPa} /$ day), which is also considered a mild imposition of water deficit (Sobieh et al., 2004). To confirm this, the chlorophyll levels in the FFEleaves and SFE-leaves of the stolon was measured and it was noted an increase of chlorophyll conntent of FFE-leaves and slight decrease in SFE-leaves, while more severe water stress is known to significantly reduce chlorophyll in leaves (Beltrano et al., 1999; Young et al., 2004). Thus in white clover, it is likely that a slower rate of imposition does not lead to any significantly sustained increase in ethylene production, in common with other studies (Yang et al., 2006). In leaf tissue of intact plants, where small increases in ethylene production have been measured, this has been shown to be transient in nature occurring over the initial part of the dry-down with leaf water potentials typically ranging from -0.3 MPa to -1.9 MPa (Stumpff \& Johnson 1987; Irigoyen et al., 1992; Beltrano et al., 1999, Kalantari et al,. 2000, Sobeih et al., 2004). In this study, the increase has been shown to coincide with an LWP range of $-0.8-1.8 \mathrm{MPa}$ in the FFE-levaes.

For $\mathrm{AC} 0$, previous characterization of the ACO multi-gene family has been undertaken in white clover and three genes have been shown to undergo differential expression during leaf development (McManus et al., 1999). The TR-ACO1 expressed in the apex, TR-CO2 expressed in mature green leaves while TR-ACO3 expressed in the yellowing and senescent-leaves (McManus et al., 1999). 
Therefore, changes in the expression of these TR-ACO genes may be corresponding to responses of white clover to stress stimuli. In the FFE leaf tissue examined here, two of the three TR-ACO genes are known to be expressed at this developmental stage but no increase in transcription in response to the water deficit in the Apex. A third ACOgene, TR-ACO, is normally expressed in older and senescing leaves, and expression was also slightly increased in the SFE-leaves at different SWC in this study. This suggests that these tissues were exhibiting a slight accelerated aging or wounding responses (as also confirmed by the chlorophyll data). Increases in ACC levels were originally reported in response to drought using detached leaves (Apelbaum \& Yang 1981), but using whole wheat seedlings, an increase in ACC levels was only observed in response to a faster rate of dehydration (Yang et al., 2006). In the milder treatment, no change in ACC levels were reported, a trend also observed in field grown Rosemary plants (Munne-Bosch et al., 2002). Fewer studies have reported changes in ACO gene expression, but an induction of ACS6 and ACS7 has been reported in hydroponically grown 7-day-old seedlings of Arabidopsis that were exposed to an osmotic stress treatment using $200 \mathrm{mM}$ mannitol (Kreps et al., 2002), while a decrease in the expression of ACS4 has been observed in Arabidopsis seedlings exposed to a water with-holding treatment until the leaf RWC reduced by $25 \%$ (Wilkins et al,. 2010).

The expression of ACO has been shown to be influenced by water deficit both in terms of an increase or decrease of transcription observed (Ouvarard et al., 1996; Kreps et al., 2002; Seki et al., 2002; Huang et al., 2008). However, these studies have not related any changes in expression observed to signature physiological markers of a water deficit, or whether the gene family members are normally expressed in the particular tissue at the specific developmental stage examined. For the current study, therefore, we focused on the expression and accumulation of three of the vegetativetissue-associated ACOs of white clover at the developmental stages in which these genes are normally expressed. For TR-ACO1, changes in gene expression and TR-ACO1 accumulation were examined in the apical structure of the stolon as previous studies had shown that expression of this gene (using TR-ACO1::GUS reporter constructs) is associated with meristematic and ground meristem tissue (Chen and McManus 2006). Recently it has been shown that ethylene may play a role in arresting the cell cycle in proliferating leaves of Arabidopsis in response to osmotic stress (to create a 'pause' in growth (Skirycz et al., 2011). However no concomitant increase in ACO expression was oassociated bserved, although as the drought was prolonged then AtACCO1 was induced. In the apical structures of the white clover stolon, no change in TR-ACO1 expression or TR-ACO1 accumulation was observed. It is known from other drought studies that the enclosed apical meristematic (or intercalary) structures are preferentialy protected (West et al., 1990; Hare \& Cress, 1996; Abernethy et al. 1998; Clark et al. 2004) and so the tightly ensheathed structure of the stolon meristem (including the axillary meristems) of white clover may also be buffered from changes in the SWC. No change in TR-ACO1 expression or TR-ACO1 accumulation would support this notion and can confer an ecological advantage to stoloniferous habit in drought recovery.

For TR-ACO2 expression and TR-ACO2 accumulation, changes in the first-fully expanded leaf of the stolon were examined, as this is the leaf developmental stage in which expression of the gene and accumulation of the protein is optimal (Hunter et al. 1999; Gong \& McManus, 2000; Chen \& McManus, 2006). In this experiment, no significant change in TR-ACO2 was observed in common with other studies using leaf tissues (Kreps et al., 2002; Huang et al., 2008; Wilkins et al., 2010). However, an increase in TR-ACO2 accumulation was observed, particularly over the later part of the dry-down time course. This increase correlated with an increase in total chlorophyll and dramatic increase in proline levels (suggesting the onset of a cellular stress), provided us with a discernable bi- 
phasic time-course. The first phase comprised the tightly-regulated decrease in PER with a decrease in SWC (at ca. 28 - 10\% SWC), while the second was marked by the onset of defined metabolic changes associated with osmolyte and osmoprotectant biosynthesis just prior to the total cessation of growth (ca. $10-8 \%$ SWC.

This examination of the tight regulation of ACO expression and accumulation in the first fully expanded leaf was extended to an older leaf as it has been observed that any predisposition of leaves to succumb to the effects of a water stress in terms of entry into the senescence syndrome was more marked in older tissues (Sobeih et al., 2004; Young et al., 2004). Again, to determine the effects of the water deficit, we firstly measured chlorophyll levels but did not note any change in the SFE leaves suggesting that the drought treatment was not severe enough to induce any pre-mature senescence (as also shown by the non-induction of the senescence-associated TR-ACO3 gene). We do know that TR-ACO3 can be induced in mature-green leaves, a tissue in which it is not expressed during normal leaf ontogeny, in response to wounding (Scott et al., 2010). In this older leaf, we found that the changes in TR-ACO2 expression and TR-ACO2 accumulation did occur and showed a similar pattern to that observed for the first fully-expanded leaf.

We do not know why the induction of ACO gene expression and protein accumulation in the FFE leaf tissue did not result in an increase in ethylene evolution. We do know from this study, and previously (Hunter et al., 1999) that the rate of ethylene evolution measured from the leaves is very low, and so any localized increase in ethylene evolution in response to quite tissue-limited induction of ethylene biosynthesis gene expression may be undetectable. We know that the water deficit stress we have imposed is not a significant one as the PER ceased at ca. $-1.8 \mathrm{MPa}$ (-18 bar), and in the FFE leaves, no induction of the senescence-associated TR-ACO3 gene was observed. What we can say though is at the early stages of a drought, when the dry-down is imposed gradually, then significant changes in ACO expression do occur. While TR-ACO1 expression in the apex and TR-ACO3 expression in the FFE- and SFE-leaves did show tight regulation with respect to the SWC, the induction of TR_ACO2 did occur. Together these observations underline the exquisite nature and tiers of control of the pathway in response to a water deficit. Further, we can now add that these changes also include the genes and proteins that comprise the ethylene biosynthetic pathway. Thus these changes may be part of a intrinsic mechanism by which plants cope and respond to the early stages of a drought as it is widely accepted that ethylene can both inhibit and promote root and shoot growth depending on the prevailing developmental and environmental cues.

\section{CONCLUSION}

Water deficit altered the LWP, PER, chlorophyll, proline, ACC-Oxydase gene expression and protein accumulation in white clover. The total chlorophyll and proline content of the FFE leaf increased by water deficit below 14\%. In addition, a water deficit stimulated expression and accumulation of TRACO gene and protein in the FFE leaf tissue, but did not change these in the apex and the SFE leaf tissue. These results show that ethylene biosynthesis regulate white clover responses to water deficit, both in the genes and proteins that comprise the ethylene biosynthetic pathway.

\section{ACKNOWLEDGEMENT}

The authors wish to sincerely thank New Zealand Agency for International Development for providing Ph.D. scholarship to Mrs. Aluh N. 


\section{AUTHORS' CONTRIBUTIONS}

Author 1 conducted the experiments, interpreted the results and wrote the manuscript under the supervision of Author 2 and Author 3. The Author 4 contributed by assisting molecular biology methods used in this experiment.

\section{REFERENCES}

Abernethy, G.A., Fountain, D.W., \& McManus, M.T. (1998). Observations on the leaf anatomy of Festuca novae-zelandiae (Hack.) Cockayne and biochemical responses to a water deficit. New Zealand Journal of Botany, 36, 113-123.

Apelbaum, A., \& Yang, S.F. (1981). Biosynthesis of stress ethylene induced by water deficit. Plant Physiol., 68, 594-596.

Beltrano, J., Ronco, M.G., \& Montaldi, E.R. (1999). Drought stress syndrome in wheat is provoked by ethylene evolution imbalance and reversed by rewatering, aminoethoxyvinylglycine, or sodium benzoate. Journal of Plant Growth Regulation, 18, 59-64.

Bleecker, A.B., \& Kende, H. (2000). Ethylene: a gaseous signal molecule in plants. Annual Review of Cell and Developmental Biology, 16, 1-18.

Chen, B.C., \& McManus, M.T. (2006). Expression of 1-aminocyclopropane-1-carboxylate (ACC) oxidase genes during the development of vegetative tissues in white clover (Trifolium repens $\mathrm{L}$.) is regulated by ontological cues. Plant Molecular Biology, 60, 451-467.

Chen, K.M., Gong, H.J., Chen, G.C., \& Zhang, L. (2002) ACC and MACC biosynthesis and ethylene production in water-stressed spring wheat. Acta Botanica Sinica, 44(7), 775-781.

Clark, G.T., Zuther, E., Outred, H.A., McManus, M.T., \& Heyer, A.G. (2004). Tissue-specific changes in remobilisation of fructan in the xerophytic tussock species Festuca novae-zelandiae in response to a water deficit. Functional Plant Biology, 31, 377-389.

Gong, D., \& McManus, M.T. (2000). Purification and characterization of two ACC oxidase expressed differentially during leaf ontogeny in white clover. Physiologia Plantarum, 110, 13-21.

Guerfel, M., Baccouri, O., Boujnah, D., Chaibi, W., \& Zarrouk, M. (2009). Impacts of water stress on gas exchange, water relations, chlorophyll content and leaf structure in the two main Tunisian olive (Olea europaea L.) cultivars. Science Horticulture, 119, 257-263.

Har, P.D., \& Cress, W.A. (1996). Tissue-specific accumulation of transcript encoding D ${ }^{1}$-pyrrolline5-carboxylate reductase in Arabidopsis thaliana. Plant Growth Regulation, 19, 249-256.

Higgins, J.D., Newbury, H.J., Barbara, D.J., Muthumeenakshi, S., \& Puddephat, J.J. (2006) The production of marker-free genetically engineered broccoli with sense and antisense ACC synthase 1 and ACC oxidase 1 and 2 to extend shelf-life. Molecular Breeding, 17 (1), 7-20.

Huang, D., Wu, W., Abrahms, S.R., \& Cutler, A.J. (2008). The relationship of drought-related gene expression in Arabidopsis thaliana to hormonal and environmental factors. J Exp Botany, 59(11), 2991-3007.

Hunter, D.A., \& Reid, M.S. (2001). A simple and rapid method for isolating high quality RNA from flower petals. Acta Hort, 543, 147-152.

Hunter, D.A., Yoo, S.D., Butcher, S.M., \& McManus, M.T. (1999). Expression of 1aminocyclopropane-1-carboxylate oxidase during leaf ontogeny in white clover. Plant Physiol., $120,131-142$. 
Inskeep, W.P., \& Bloom, P.R. (1985). Extinction coefficients of chlorophyll-a and chlorophyll-b in N,N-Dimethylformamide and 80-percent acetone. Plant Physiol., 77, 483-485.

Javadi, T., Arzani, K., \& Ebrahimzadeh, H. (2006). Study of proline, soluble sugar, and chlorophyll a and $\mathrm{b}$ changes in nine Asian and one European pear cultivar under drought stress. Zhang D, Lee JM, Tao R (eds), Proceedings of The International Symposium on Asian Plants with Unique Horticultural Potential, pp. 241-246.

Kalantari, K., Smith, A.R., \& Hall, M.A. (2000). The effect of water stress on 1(malonylamino)cyclopropane-1-carboxylic acid concentration in plant tissues. Plant Growth Regulation, 31, 183-193.

Kreps, J.A., Wu, Y., Chang, H.S., Zhu, T., Wang, X., \& Harper, J.F. (2002). Transcriptome changes for Arabidopsis in response to salt. Osmotic, and cold stress. Plant Physiol., 130, 2129-2141.

Laemmli, U. (1970) Cleavage of structural proteins during the assembly of the head of Bacteriophage T4. Nature, 227, 680-685. https://doi.org/10.1038/227680a0

Magna, C., \& Larher, F (1984). High sugar content of extracts interferes with colorimetric determination of amino acids and free proline. Analytical Biochemistry, 200, 115-118.

McManus, M.T., Bieleski, R.L., Caradus, J.R., \& Barker, D.J. (2000). Pinitol accumulation in mature leaves of white clover in response to a water deficit. Environmental and Experimental Botany, 43, 11-18.

McManus, M.T., Hunter, D.A., Yoo, S.D., \& Gong, D. (1999). ACC Oxidase Expression and Leaf Ontogeny in White Clover. In: Kanellis A.K., Chang C., Klee H., Bleecker A.B., Pech J.C., Grierson D. (eds), Biology and Biotechnology of the Plant Hormone Ethylene II. Springer, Dordrecht. https://doi.org/10.1007/978-94-011-4453-7_27

Munne-Bosch, S., Lopez-Carbonell, M., Alegre, L., \& van Onckelen, H.A. (2002). Effect of drought and high solar radiation on 1-aminocyclopropane-1-carboxylic acid and abscisic acid concentrations in Rosmarinus officinalis plants. Physiologia Plantarum, 114, 380-386.

Ouvrard, O., Collier, F., Ferrare, K., Tousch, D., \& Lamaze, T. (1996). Identification and expression of water stress- and abscisic acid-regulated genes in a drought-tolerant sunflower genotype. Plant Molecular Biology, 31, 819-829.

Ramasamy, G., Babu, B., Chandra, K., Shankar, M., \& Prakash, O. (2017). Effect of Moisture stress on Key Physiological traits in Brinjal (Solanum melongena L.) Cultivars. Vegetos- An International Journal of Plant Research, 30, 403 - 408. https://doi.org/10.5958/22294473.2017.00108.2.

Ravi, S., Breshears, D.D., Huxman, T.E., \& D’Odorico, P. (2010) Land degredataion in drylands: Interactions among hydrological-aeolian erosion and vegetation dynamics. Geomorphology, 116(3-4), 236-245.

Rieu, I., Cristescu, .SM., Harren, F.J.M., Huibers, W., Voesenek, L.A.C.J., Mariani, C., \& Vriezen, W.H. (2005). RP-ACS1, a flooding-induced 1-aminocyclopropane-1-carboxylate synthase gene of Rumex palustris, is involved in rhythmic ethylene production. Journal of Experimental Botany, 56 (413), 841-849.

Rodriguez-Uribe, \& O'Connell, M.A. (2006). A root-specific bZIP transcription factor is responsive to water deficit stress in tepary bean (Phaseolus acutifolius) and common bean ( $P$. vulgaris). Journal of Experimental Botany, 57 (6):1391-1398.

Sanchez, F.J., de Andres, E.F., Tenorio, J.L., \& Ayerbe, L. (2004). Growth of epicotyls, turgor maintenance and osmotic adjustment in pea plants (Pisum sativum L.) subjected to water stress. Field Crops Research, 86(1), 81-90. 
Schroeder, J.I., Kwak, J.M., \& Allen, G.J. (2001). Guard cell abscisic acid signaling and engineering drought hardiness in plant. Nature, 410, 327-330.

Scott, R.W., Yoo, S.D., Hunter, D.A., Gong, D., Chen, C.-M., Leung, S., \& McManus, M.T. (2010). Regulation of 1-aminocyclopropane-1-carboxylate oxidase gene expression during leaf ontogeny in white clover. Plant Growth Regulation, 62, 31-41.

Seki, M., Narusaka, M., Ishida, J., Nanjo, T., Fujita, M., Oono, Y., Kamiya, A., Nakajima, M., Enju, A., Sakurai, T., Satou, M., Akiyama, K., Taji, T., Yamaguchi-Shinozaki, K., Carninci, P., Kawai, J., Hayashizaki, Y., \& Shinozaki, K. (2002). Monitoring the expression profiles of 7000 Arabidopsis genes under drought, cold and high-salinity stresses using a full-length cDNA microarray. The Plant Journal, 31, 279-292.

Skirycz, A., \& Inze, D. (2010). More for less: Plant growth under limited water. Curr Opin Biotechnol, 21, 197-203.

Skirycz, A., Claeys, H., De Bodt, S., Oikawa, A., Shinoda, S., Andriankaja, M., Maleux, K., Eloy, N.B., Coppens, F., Yoo, S.-D., Saito, K., \& Inze, D. (2011). Pause-and-stop: The effects of osmotic stress on cell proliferation during early leaf development in Arabidopsis and a role for ethylene signalling in cell cycle arrest. Plant Cell, 23, 1876-1888.

Sobeih, W.Y., Dodd, I.C., Bacon, M.A., Grierson, D., \& Davies, W.J. (2004). Long-distance signals regulating stomatal conductance and leaf tissue growth in tomato (Lycopersicon esculentum) plants subjected to partial root-zone drying. Journal of Experimental Botany, 55, 2353-2363.

Stumpff, N.J., \& Johnson, J.D. (1987). Ehtyleen production by loblolly pine seedlings with water stress. Physiol. Plant, 69, 167-172.

Tanaka, Y., Sano, T., Jamacki, M., Nakajima, N., Kondo, N., \& Hasezawa, S. (2005) Ethylene inhibits abscisic-acid-induced stomatal closure in Arabidopsis. Plant Physiology, 138(4), 23372343 .

Wang, K.L.C., Li, H., \& Ecker, J.R. (2002). Ethylene biosynthesis and signaling networks. Plant Cell, 14, S131-S151

West, C.P., Oosterhuisa, D.M., \& Wullschleger, S.D. (1990). Osmotic adjustment in tissues of tall fescue in response to water deficit. Environmental and Experimental Botany, 30, 149-156.

Wilkins, O., Brautigam, K., \& Campbell, M.M. (2010). Time of day shapes Arabidopsis drought transcriptomics. Plant J., 63, 715-727.

Yang, J., Zhang, J., Liu, K., Wang, Z., \& Liu, L. (2006). Abscisic acid and ethylene interact in wheat grains in response to soil drying during grain filling. New Phytologist, 171, 293-303.

Yang, S.F., \& Hoffmann, N.E. (1984). Ethylene biosynthesis and its regulation in higher plants. Annual Review of Plant Physiology and Plant Molecular Biology, 35, 155-189.

Young, T.E., Meeley, R.B., \& Gallie, D.R. (2004). ACC synthase expression regulates leaf performance and drought tolerance in maize. Plant Journal, 40, 813-825. 